\title{
Hemoglobin Electrophoresis and Hemoglobinopathies in Kuwait
}

\author{
R. Maroufa T.M. D'souza ${ }^{b}$ A.D. Adekile ${ }^{b}$ \\ Departments of a Pathology and ${ }^{\mathrm{b} P e d i a t r i c s, ~ F a c u l t y ~ o f ~ M e d i c i n e, ~ K u w a i t ~ U n i v e r s i t y, ~ K u w a i t ~}$
}

\section{Key Words}

Hemoglobin electrophoresis · Sickle cell anemia $\cdot \alpha$ - and $\beta$-thalassemia $\cdot$ Kuwait

\begin{abstract}
Objectives: To analyze the results of hemoglobin electrophoresis (HE) in the routine laboratory of a tertiary hospital in Kuwait and to review the common types of hemoglobinopathies prevalent in the country. Methods: This was a prospective study of HE performed on 2,386 samples in Mubarak Al-Kabeer Hospital, which serves more than $30 \%$ of the population of Kuwait, from June 1997 to May 1998. Results: Of the 2,386 HE tests, only 561 $(23.5 \%)$ had abnormal hemoglobin genotypes. The most commonly identified hemoglobinopathies were $\beta$-thalassemia minor $(14 \%)$, sickle cell trait $(6 \%)$, sickle cell anemia $(0.9 \%), S \beta^{0}$ thal $(0.8 \%)$ and $S \beta^{+}$thal $(0.8 \%)$. Two rare hemoglobin variants, $\mathrm{Hb} \mathrm{D}_{\text {Punjab }}$ and $\mathrm{Hb} \mathrm{E}$, were encountered. Conclusion: HE yielded only $23.5 \%$ abnormal results, thus indicating the need to streamline requests for the test. The test should be limited to patients with hematological and clinical features suggestive of hemoglobinopathies or to individuals with a positive family history.
\end{abstract}

Copyright $@ 2002$ S. Karger AG, Basel

\section{Introduction}

Mubarak Al-Kabeer Hospital is the major teaching facility of the Faculty of Medicine, Kuwait University. Located in the largest of Kuwait's five governorates, it covers about $30 \%$ of the overall population of 2.2 million people. Anemia is a major medical problem in Kuwait, and a recent study using WHO guidelines found more than $40 \%$ of children and adolescents to be anemic [1]. Hemoglobin electrophoresis (HE) is a specialized test that is done to diagnose certain types of hemolytic anemias (hemoglobinopathies) due to abnormal structural hemoglobins $(\mathrm{Hb})$ and the thalassemia syndromes. HE also detects the carrier state of such diseases, which is important in family counseling. Since hemoglobinopathies are prevalent in the Arabian Peninsula [2-5], many physicians routinely request $\mathrm{HE}$ in the initial investigation of anemia based mainly on clinical suspicion.

In the Hematology Department of Mubarak Hospital, we have noticed a vast number of requests for HE test, the majority of which do not appear to have clear justification. An audit of HE has not yet been carried out. However there was a previous study of the prevalence of hemoglobinopathies in Kuwait in 1993 [2].

The present study was designed to prospectively analyze all samples sent to the Hematology Laboratory for $\mathrm{HE}$ to ascertain its usefulness in the diagnosis of hemoglobinopathies and to further review the common types of hemoglobinopathies that are prevalent in the country.

\footnotetext{
Dr. Rajaa Marouf

Department of Pathology, Faculty of Medicine

PO Box 24923

13110 Safat (Kuwait)

Tel. +965 5312300, Fax +965 5342575, E-Mail r-marouf@hsc.kuniv.edu.kw
} 


\section{Materials and Methods}

Routine HE was performed on all samples for which the test was requested from June 1997 to May 1998. The following were carried out on each sample, prior to the HE run: complete blood count (CBC) using a Coulter counter (model STKR), sickling test, blood smear and reticulocyte stain. A fresh hemolysate was prepared, which was used for the HE on cellulose acetate medium at an alkaline $\mathrm{pH}$. The relative concentrations of the $\mathrm{Hb}$ bands were determined by densitometry. All abnormal results were crosschecked on citric acid gel electrophoresis. The $\mathrm{Hb} \mathrm{A}_{2}$ levels were also checked using microcolumn chromatography, while fetal $\mathrm{Hb}(\mathrm{Hb} \mathrm{F})$ was determined using the alkali-denaturation technique. These procedures and techniques were done as recommended by Dacie and Lewis [6]. The results were then reported by hematologists following a review of the CBC findings, blood films, reticulocyte stains, examination of the HE strips and densitometric graphs.

\section{Results}

A total of 2,386 HE tests were done during the study period at an average of 200 per month. Correspondingly an equal number of $\mathrm{CBC}$, blood films, reticulocyte preparations, sickling tests, $\mathrm{Hb} \mathrm{A}_{2}$ and $\mathrm{Hb} \mathrm{F}$ estimations were performed. The vast majority, $182(76.5 \%)$ of the HE tests had a normal Hb AA pattern, while only 561 (23.5\%) were abnormal or positive for hemoglobinopathy.

Table 1 shows the distribution of the $\mathrm{Hb}$ genotypes identified. The most commonly identified abnormal pattern was $\mathrm{A} / \mathrm{A}_{2}$, i.e. $\beta$-thalassemia minor (14\%). Sickle cell trait (AS), sickle cell anemia with elevated $\mathrm{Hb} F(\mathrm{SF})$, $\mathrm{S} \beta^{+}$thal $\left(\mathrm{S} / \mathrm{A} / \mathrm{A}_{2}\right)$ and $\mathrm{S} \beta^{0}$ thal $\left(\mathrm{S} / \mathrm{F} / \mathrm{A}_{2}\right.$ and $\left.\mathrm{S} / \mathrm{A}_{2}\right)$ were 6 , $0.9,0.8$ and $0.8 \%$, respectively. Two patients with $\mathrm{F} / \mathrm{A}_{2}$ and a patient with F/A had $\beta$-thalassemia major. Most of the individuals with AF pattern were infants below 6 months of age. The two rare $\mathrm{Hb}$ variants detected in this study were $\mathrm{Hb} \mathrm{D}$ with 6 heterozygotes (AD) and 1 compound heterozygote $\left(\mathrm{A} / \mathrm{D} / \mathrm{A}_{2}\right.$ i.e. $\mathrm{D} \beta^{+}$-thal $)$and $\mathrm{Hb} \mathrm{E}(\mathrm{EF})$. These rare variants were confirmed with cation-exchange high performance liquid chromatography (HPLC).

\section{Discussion}

Considerable resources (both manpower and financial) are expended on running $\mathrm{HE}$ in the routine hematology laboratory. For every sample, $\mathrm{CBC}$ is done along with blood film examination for red blood cell (RBC) morphology and staining both for reticulocyte count and $\mathrm{H}$ inclusions. The latter, when present, is suggestive of an $\alpha$-thalassemia state. For meaningful interpretation of HE result,
Table 1. Frequencies of different Hb genotypes detected

\begin{tabular}{lrl}
\hline Hb genotype & Number & Percentage \\
\hline $\mathrm{AA}$ & 1,826 & 76.5 \\
$\mathrm{~A} / \mathrm{A}_{2}$ & 335 & 14 \\
$\mathrm{~A} / \mathrm{S}$ & 143 & 6 \\
$\mathrm{~S} / \mathrm{F}$ & 22 & 0.9 \\
$\mathrm{~A} / \mathrm{S} / \mathrm{A}_{2}$ & 19 & 0.8 \\
$\mathrm{~S} / \mathrm{F} / \mathrm{A}_{2}$ & 11 & 0.8 \\
$\mathrm{~A} / \mathrm{F}$ & 10 & 0.4 \\
$\mathrm{~A} / \mathrm{D}$ & 6 & 0.3 \\
$\mathrm{~A} / \mathrm{E}$ & 3 & 0.1 \\
$\mathrm{~A} / \mathrm{F} / \mathrm{A}_{2}$ & 3 & 0.1 \\
$\mathrm{~F} / \mathrm{A}_{2}$ & 2 & 0.08 \\
$\mathrm{~A} / \mathrm{D} / \mathrm{A}_{2}$ & 1 & 0.04 \\
$\mathrm{~S} / \mathrm{A}_{2}$ & 1 & 0.04 \\
F/A & 1 & 0.04 \\
E/F & 1 & 0.04 \\
Unknown & 3 & 0.1 \\
\hline Total & 2,386 & 100 \\
\hline
\end{tabular}

$\mathrm{Hb} \mathrm{A}_{2}$ should be estimated by microcolumn chromatography, especially when there is $\mathrm{Hb} \mathrm{S}$ in the sample. This is because some denatured $\mathrm{Hb} \mathrm{S}$ may comigrate with $\mathrm{Hb} \mathrm{\textrm {A } _ { 2 }}$ on electrophoresis. In certain situations, when optimal separation of bands is desired, citrate gel electrophoresis may have to be done to identify the abnormal $\mathrm{Hb}$ variant(s). During the year under study, about 200 runs were made every month, giving a total of 2,386 with only $23.5 \%$ showing abnormal or positive results, indicating the poor yield of the test. There is, therefore, a need to streamline requests such that the yield from HE can be improved.

The commonest cause of anemia, especially when it is hypochromic and microcytic, is iron deficiency. In any situation when there is no strong family history or other circumstances to suggest an inherited hemolytic anemia, iron deficiency should be initially ruled out before further testing is carried out. This can be achieved by using appropriate tests of iron status and/or a therapeutic trial of iron. If the tests are negative and/or there is no response to iron, then HE is justified, to rule out thalassemia, bearing in mind that the test will help in identifying most cases of $\beta$-thalassemia (minor or major). $\alpha$-Thalassemia trait, on the other hand, may be difficult to diagnose with this test and may require molecular techniques. In a situation where a sickling disorder is suspected on clinical grounds or because of a positive family history, an initial sickling 


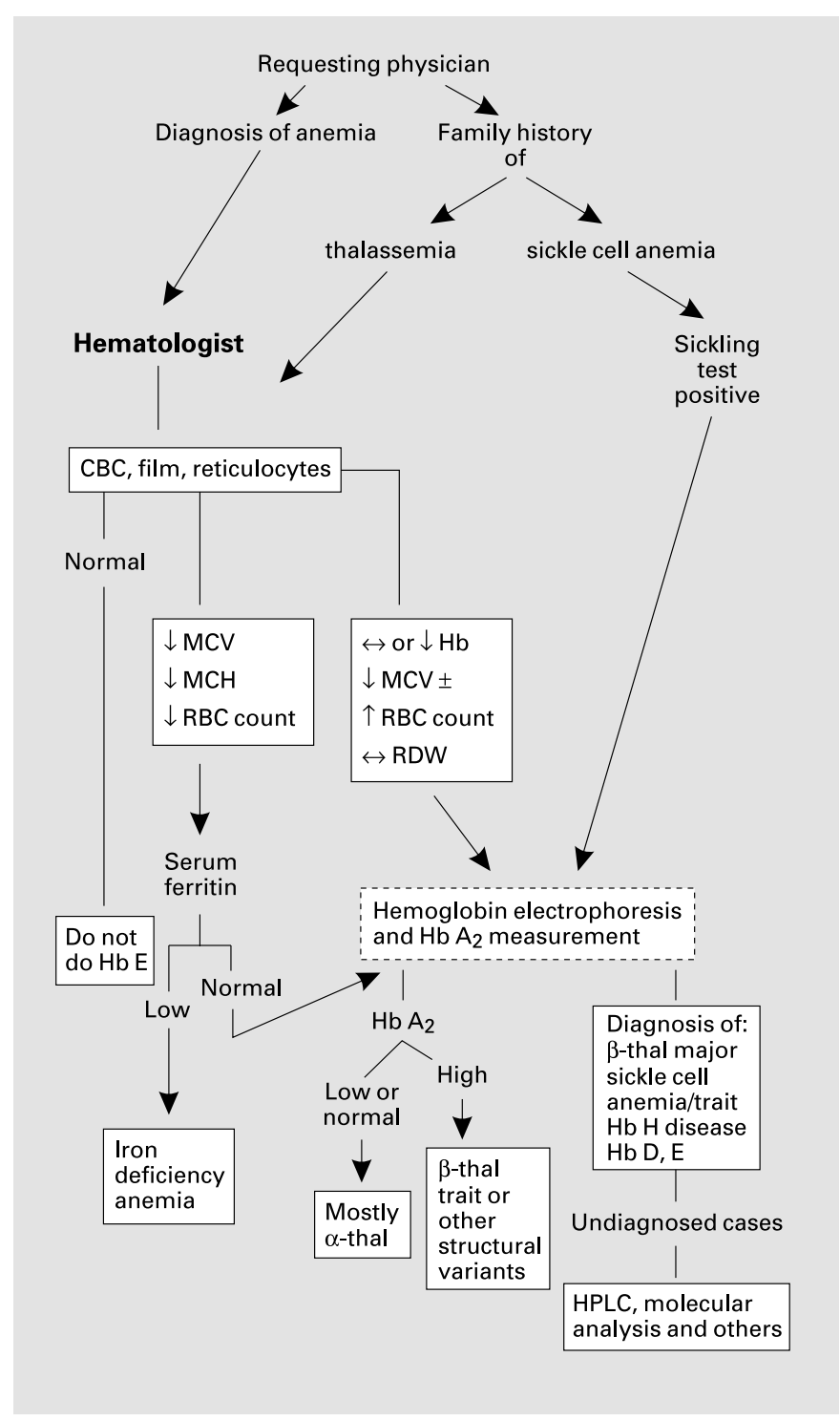

Fig. 1. Flowchart showing the suggested scheme for investigating hemoglobinopathies. $\mathrm{MCV}=$ Mean corpuscular volume; $\mathrm{MCH}=$ mean cell hemoglobin; RDW $=$ red cell distribution width .

test should be done and it is only when this is positive, that $\mathrm{HE}$ is justified. A flowchart is provided in figure 1 that shows the steps to be followed in the workup of a suspected case of hemoglobinopathy.

The present study showed that the most commonly identified hemoglobinopathy traits in Kuwait are $\beta$-thal and $\mathrm{Hb} \mathrm{S}$. The pattern of $\mathrm{Hb}$ variants and genotypes is similar to that previously reported [2], except that $\mathrm{Hb} \mathrm{J}$ and $\mathrm{Hb}$ Lepore were not encountered. The only rare variants in the present study were $\mathrm{Hb} \mathrm{D}$ and $\mathrm{Hb} \mathrm{E}$. The for- mer, also known as $\mathrm{Hb} \mathrm{D}_{\text {Punjab }}$ or $\mathrm{D}_{\text {Los Angeles, }}$ is a $\beta$-globin chain variant in which glycine is substituted for glutamate in the 121 st amino acid position. It is most common in the Indus valley, but is quite widespread. Its mobility is similar to $\mathrm{Hb} \mathrm{S}$ in an alkaline medium and it does not separate in an acidic medium. That is why its presence was confirmed by cation-exchange HPLC. Hematological parameters are usually normal in heterozygotes and homozygotes $[7,8]$. However, in combination with $\mathrm{Hb} \mathrm{S}$, it presents a severe sickling disorder and in combination with $\beta$-thal ( $\mathrm{D} \beta^{0}$-thal), it causes moderate hypochromic, microcytic anemia $[9,10]$.

$\mathrm{Hb} \mathrm{E}$ is also a $\beta$-globin chain variant in which lysine substitutes for glutamate in the 26th amino acid position. It causes mild microcytosis in the heterozygote and normal to mild anemia in the homozygote. When coinherited with $\beta$-thal trait, it may cause severe anemia and the patient may be transfusion-dependent. It can be separated from $\mathrm{Hb} \mathrm{A}$ at an alkaline, but not acidic $\mathrm{pH}$. While it separates well from $\mathrm{Hb} \mathrm{A}$ on cation-exchange HPLC, it may coelute with $\mathrm{Hb} \mathrm{A}_{2}[7,8]$.

It should be noted that most $\mathrm{Hb} \mathrm{S}$ homozygotes in the present study have a significant elevation of $\mathrm{Hb} F$, such that the genotype is reported as $\mathrm{S} / \mathrm{F}$ and the compound heterozygote with $\beta$-thal is reported as $S / F / A_{2}$. This is because the $\beta^{\mathrm{S}}$-globin gene mutation in most Kuwaitis is on a chromosome with the Saudi Arabia/India haplotype [11]. This haplotype is associated with the $-158(\mathrm{C} \rightarrow \mathrm{T})$ mutation on the ${ }^{\mathrm{G}} \gamma$-globin gene and as such the patients have persistently elevated $\mathrm{Hb} F$ levels, even as adults.

\section{Conclusion}

$\mathrm{HE}$ is one of the most frequently requested tests in the routine hematology laboratory. Quite often, however, it may not be justified. In the present study, only $23.5 \%$ of the tests yielded a positive result. There is, therefore, a need to streamline requests to make the test cost-effective. It should be limited to individuals with clinical and/or hematological parameters suggestive of a hemoglobinopathy and in individuals with a positive family history. 


\section{References}

1 Jackson RT, Al-Mousa Z, Adekile AD, Mughal HA, Nkansa-Dwamena DK: The prevalence and etiology of anemia in Kuwait preschoolers and adolescents. Kw Med J 1999;31:33-39.

2 Ghosh K, Shaqalaih A, Salman A, Hassanein AA: Haemoglobinopathies in a large hospital in Kuwait. Haematologia (Budap) 1993;25:185190.

3 Adekile AD, Haider MZ: Genetic epidemiology of sickle cell anemia and $\alpha / \beta$-thalassemia in Kuwait. J Kw Med Assoc 1996;28:104-110.

4 El-Hazmi MAF: Genetic red cell disorders in Saudi Arabia: A multifaceted problem. Hemoglobin 1994;18:257-272.
5 White JM, Byrne M, Richards R, Buchnan T, Katsoulis E, Weerasinghi K: Red cell genetic abnormalities among Peninsular Arabs: Sickle hemoglobin, G6PD deficiency and alpha and beta thalassemia. J Med Genet 1986;23:245251.

6 Dacie JW, Lewis SM: Practical Haematology, ed 8. Edinburgh, Churchill Livingstone, 1995, pp 227-257.

7 Huisman THJ (ed): The Hemoglobinopathies: Methods in Hematology. Edinburgh, Churchill Livingstone, 1986, vol 15, pp 1-31.

8 Flint J, Harding RM, Boyce AJ, Clegg JB: The population genetics of haemoglobinopathies. Baillières Clin Haematol 1993;6:215-262.
9 El-Kalla S, Matthews AR: Hb D-Punjab in the United Arab Emirates. Hemoglobin 1996;21: 369-375.

10 Adekile AD, Kazanetz EG, Leonova JY, Marouf $\mathrm{R}$, Khamis A, Huisman THJ: Co-inheritance of $\mathrm{Hb}$ D-Punjab and ßo-thalassemia. J Pediatr Hematol Oncol 1996;18:151-153.

11 Adekile AD, Gu LH, Baysal E, Haider MZ, AlFuzae L, Aboobacker KC, Al-Rashied A, Huisman THJ: Molecular characterization of $\alpha$-thalassemia determinants, $\beta$-thalassemia alleles and BS haplotypes among Kuwaiti Arabs. Acta Haematol 1994;92:176-181. 